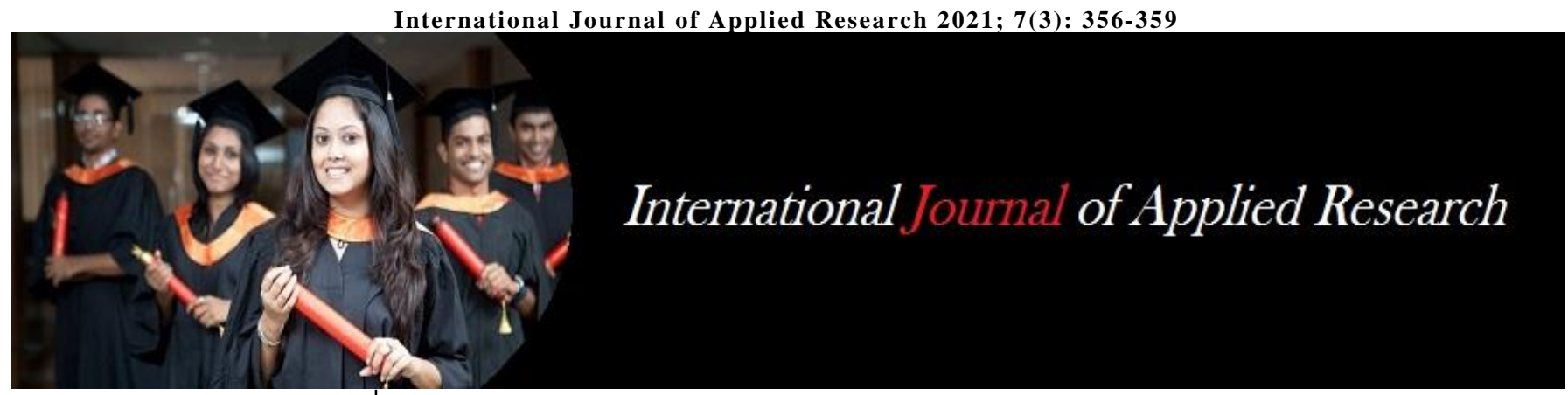

ISSN Print: 2394-7500 ISSN Online: 2394-5869 Impact Factor: 8.4 IJAR 2021; 7(3): 356-359 www.allresearchjournal.com Received: 16-01-2021 Accepted: 18-02-2021

\section{Dr. M Renukadevi}

Associate Professor,

Department of Corporate

Secretaryship, PSG College of

Arts and Science, Coimbatore,

Tamil Nadu, India

\section{GA Hema}

Assistant Professor, Department of Commerce, PSG College of Arts and Science, Coimbatore,

Tamil Nadu, India
Corresponding Author: Dr. M Renukadevi Associate Professor, Department of Corporate Secretaryship, PSG College of Arts and Science, Coimbatore, Tamil Nadu, India

\section{A study on policy holders perception towards micro insurance with special reference to Coimbatore city}

\author{
Dr. M Renukadevi and GA Hema
}

DOI: https://doi.org/10.22271/allresearch.2021.v7.i3f.8427

Abstract

Micro insurance, commonly called as insurance for the poor, has recently drawn the attention of practitioners in developing countries. In common parlance, micro insurance is the provision of insurance services to low-income households, which serves as an important tool to reduce risks for the already vulnerable population. The main objective of the study taken was to identify and evaluate socio-economic determinants of Micro insurance, in Coimbatore city and to identify problems and issues relating to micro insurance such as product design, pricing, claim settlements. For this study Simple percentage, Mean Rank were adopted. The findings were most of the respondents are taken LIC of India, andgivenfirst priority to Premium amount. This study suggests that, lack of understanding, awareness, extension services and betterment of insurance market that grossly affect wider use of insurance products and its uptake, uniquely, among low-income groups. This paper concludes that while taking micro insurance policies was very helpful to the policyholders to run their family, to make startups, and also micro insurance become emerging trends between the policyholders.

Keywords: micro insurance, insurance, products

\section{Introduction}

Micro insurance is insurance with low premiums and low coverage. In this definition, "micro" refers to the small financial transaction that each insurance policy generates. "General micro insurance product means health insurance contract, any contract covering the belongings, such as, hut, livestock or tools or instruments or any personal accident contract, either on individual or group basis.

Micro insurance has drawn attention of the policy makers, insurers, business leaders and others in recent years. Micro insurance has been seen as one of the major risk managing tools for the poor and low income groups and a potential market for business. The sense of security linked to being insured through micro insurance augment household welfare with positive impacts. Many poor and low income households may involve in activities or enterprises of smaller scale but higher risk and uncertainty. It makes them disadvantageous because they are more prone to economic and financial collapse. Under this situation it is interesting to analyse how micro insurance can play a meaningful role in household risk managing efforts, in rural credit and insurance market and providing business opportunity.

Micro insurance is also taken as group insurance that can cover thousands of customers under one contract. It requires an intermediary between the customer and the insurance company. This intermediary role has been played mainly by non-governmental organization (NGO) and microfinance institutions (MFI), self help groups (SHG).

\section{Review of Literature}

Christina Maria Roy, et al. (2019) ${ }^{[1]}$, made a study on "Micro insurance policies with special reference to life and health insurance in India". From this study concludes that there is still a major scope of improvement in the field of micro insurance with regard to the plans initiated by the less known insurance companies and how they can overcome to become like the healthy plans and schemes.

Dilip Bania. et al. (2018) ${ }^{[2]}$, undertook a study on "Life Micro Insurance In Assam - A Case Study". 
The paper concludes that insurance companies should innovate products and distribution beyond the regulatory requirement to conduct business in the low income segment. Dr. Pritibakshi (2016) ${ }^{[3]}$, under took a study on "Review of Progress and Potential of Micro Insurance in India". This paper concludes that the development of micro insurance is both a moral and an economic imperative, not only for achieving the inclusive financial systems but also for the equitable mitigation.

\section{Objectives of The Study}

1. To identify and evaluate socio-economic determinants of micro insurance demand in Coimbatore city.

2. To identify problems and issues relating to micro insurance such as product design, pricing, claim settlements.

\section{Statement of The Problem}

Micro insurance is the protection of low-income people against specific perils in exchange for regular premium payments proportionate to the likelihood and cost of the risk involved. Low-income clients are oftenly, live in remote rural areas, and illiterate, they tend to face more risks than wealthier people do because they cannot afford the same defences. About one-fifth of household risks were related to employment followed by sudden health expenditure, bad market conditions resulting in loss of income, social problems and other type of risks. Under this situation, micro insurance which is offered by the Insurance Regulatory Development Authority can be very useful to manage their risks by low income peoples.

\section{Research Methodology}

Area of study: The area of study refers to Coimbatore city.

Sample Size: For the purpose of study 100 respondents were taken.

Sources of Data: For the purpose of study both primary and secondary data were used. The primary data is collected by Questionnaire and Interview method. The secondary data is collected through various Journals, Websites, Books, etc.

Sampling Technique: For the purpose of study Convenience sampling technique used.

Tools for analysis: Simple Percentage, Mean Rank were adopted for the study.

\section{Analysis and Interpretation}

Table 1: Demographic Factors

\begin{tabular}{|c|c|c|c|}
\hline \multicolumn{2}{|c|}{ Demographic factors } & Total no. of respondents & Percentage \\
\hline \multirow{2}{*}{ Gender } & Male & 48 & $48 \%$ \\
\hline & Female & 52 & $52 \%$ \\
\hline \multirow{4}{*}{ Age } & $18-30$ years & 20 & $20 \%$ \\
\hline & $31-40$ years & 38 & $38 \%$ \\
\hline & $41-50$ years & 15 & $15 \%$ \\
\hline & Above 50 years & 27 & $27 \%$ \\
\hline \multirow{3}{*}{ No. of family members } & 2 & 15 & $15 \%$ \\
\hline & 3 & 35 & $35 \%$ \\
\hline & $4 \&$ above & 50 & $50 \%$ \\
\hline \multirow{2}{*}{ Place } & Urban & 48 & $48 \%$ \\
\hline & Rural & 52 & $52 \%$ \\
\hline \multirow{4}{*}{ Educational qualification } & No formal education & 18 & $18 \%$ \\
\hline & School level & 37 & $37 \%$ \\
\hline & College level & 23 & $23 \%$ \\
\hline & Professional qualification & 22 & $22 \%$ \\
\hline \multirow{4}{*}{ Occupational Status } & Agriculture & 20 & $20 \%$ \\
\hline & Business & 22 & $22 \%$ \\
\hline & Employee & 28 & $28 \%$ \\
\hline & Others & 30 & $30 \%$ \\
\hline \multirow{2}{*}{ Marital status } & Married & 75 & $75 \%$ \\
\hline & Unmarried & 25 & $25 \%$ \\
\hline \multirow{2}{*}{ Nature of family } & Joint family & 18 & $18 \%$ \\
\hline & Nuclear family & 82 & $82 \%$ \\
\hline \multirow{4}{*}{ Family monthly income } & Less than Rs.10,000 & 32 & $32 \%$ \\
\hline & Rs. 10,000 to Rs. 20,000 & 18 & $18 \%$ \\
\hline & Rs. 20,001 to Rs. 30,000 & 28 & $28 \%$ \\
\hline & Rs.30,001 to above & 22 & $22 \%$ \\
\hline
\end{tabular}

Source: Primary Data

From the above table it is inferred that, $52 \%$ of respondents are female, $38 \%$ respondents are $31-40$ years, $50 \%$ of respondents are $4 \&$ above members in their family, $52 \%$ respondents are from rural place, $37 \%$ are respondents have completed their school level, $30 \%$ of the respondents are from others, $75 \%$ are married, $82 \%$ are from nuclear family, $32 \%$ respondents are have less than Rs.10000 family income. 
Table 2: Policy in Insurance Companies

\begin{tabular}{|c|c|c|}
\hline Policies & Number of respondents & Percentage \\
\hline Bajaj Allianz Life Ins. Co. Ltd. & 15 & 15.0 \\
\hline Birla Sunlife Insurance Co. Ltd. & 5 & 5.0 \\
\hline ICICI Purdential Life Ins. Co. Ltd. & 10 & 10.0 \\
\hline ING Vysya Life Insurance Co. Ltd. & 15 & 15.0 \\
\hline LIC of India & 20 & 20.0 \\
\hline Met Life India & 5 & 5.0 \\
\hline AVIVA & 10 & 10.0 \\
\hline TATA AIA & 8 & 8.0 \\
\hline SBI Life Insurance Co. Ltd & 6 & 6.0 \\
\hline Shriram Life Ins. Co. Ltd. & 6 & 6.0 \\
\hline Total & 100 & 100.0 \\
\hline
\end{tabular}

Source: Primary Data

From the above table it is inferred that, $20 \%$ of the respondents are taken LIC of India, 15\% of the respondents are taken Bajaj Allianz Life Ins. Co. Ltd. and ING Vysya Life Insurance Co. Ltd. 10\% of the respondents are taken ICICI Purdential Life Ins. Co. Ltd.,AVIVA, $8 \%$ of the respondents are taken TATA AIA, 6\% of the respondents are taken SBI Life Insurance Co. Ltd, \& Shriram Life Ins. Co. Ltd., $5 \%$ of the respondents are taken Birla Sunlife Insurance Co. Ltd.

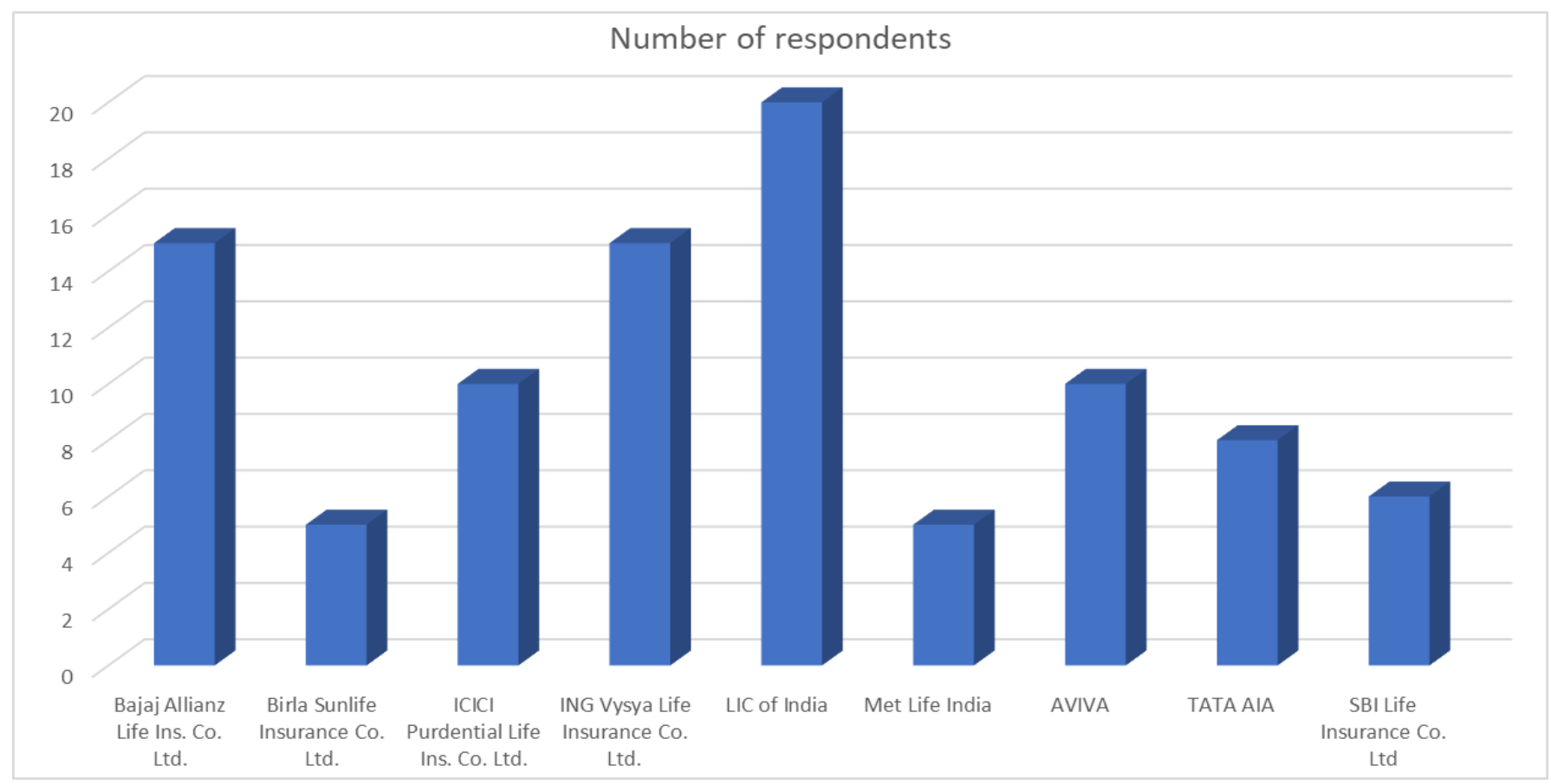

Fig 1: Policy in Insurance Companies

Table 3: Reasons for Choosing Micro Life Insurance Policy.

\begin{tabular}{|c|c|}
\hline Options & Mean Rank \\
\hline Intermediary & 3.39 \\
\hline Premium amount & 2.36 \\
\hline Returns offer & 2.95 \\
\hline Easy repayment & 3.39 \\
\hline Maturity tenure & 4.52 \\
\hline Mode of premium & 4.40 \\
\hline
\end{tabular}

Lower mean rank is given to Premium amount which shows that 2.36 is given first priority and next mean rank is given to Returns offer which shows that 2.95 is given second priority, and next mean rank is given to Intermediary and Easy repayment which shows that 3.39 is given third priority, and next mean rank is given to Mode of premium which shows that 4.40 is given fourth priority, and next mean rank is given to Maturity tenure which shows that 4.52 is given fifth priority.

\section{Findings}

1. Most (52\%) of respondents are female, $38 \%$ respondents are 31-40 years, $50 \%$ of respondents are $4 \&$ above members in their family, $75 \%$ are married, $82 \%$ are from nuclear family, $32 \%$ respondents are have less than Rs. 10000 family income.

2. Most $(20 \%)$ of the respondents are taken LIC of India.

3. Most of the respondents givenfirst priority to Premium amount.

\section{Suggestions}

1. There is lack of understanding, awareness, extension services and betterment of insurance market that grossly affect wider use of insurance products and its uptake, uniquely, among low-income groups.

2. Designing and implementing awareness campaigns and curriculum through Non Government Organizations, Self Help Group, Micro Finance Institutions in urban 
and rural areas result the augment of micro insurance market.

3. The claim settlements procedures should be shortened and make it easy to the low educated peoples.

\section{Conclusion}

Micro insurance has made steady progress. More insurers have commenced their Micro Insurance operations and many new policies are being introduced every year. For the low income people need a range of financial services, which is affordable and yet easily accessible, and should typically include credit, savings, remittances and insurance. Without insurance any improvements in alleviating poverty may be quickly lost due to the impact of risks. This study concludes with some important issues relating to micro insurance policy holders perspectives. Micro Insurance plays a significant role in improving the lives of poor households. Linking micro insurance with micro finance makes better sense as it helps in bringing down the cost of lending.

\section{References}

1. Christina Maria Roy, Elvina Varghese. "Micro insurance policies with special reference to life and health insurance in India". International Journal Of Business and Management Invention (IJBMI) 2019;08(01):83-88.

2. Dilip Bania, Dr. Sankar Thappa. "Life Micro Insurance In Assam - A Case Study", International Journal of Management Studies 2018;V(3):44-52.

3. Dr. Pritibakshi. "Review of Progress and Potential of Micro Insurance In India", International Journal of Advanced Research 2016;4(4):1669-1647.

4. Anjali Banthia, Susan Johnson, Michael J. McCord and Brandon Mathews, Gender brief.pdf, 10/30/2009.

5. Arvind M, Nayana Renukumar. Low income households \& micro insurance: understanding the needs and management challenges, 2008, 2008.

6. W.JEAN KWON, Geneva Papers on Risk \& Insurance - Issues \& Practice; Jan2010, Vol. 35 Issue 1, p130-160, 31p, 5 Charts, 3 Graphs.

7. Tinsy Rose, Selvam V. Global Management Review; 2010;4(2):7-13, 7p, 11 Charts, 3 Graphs.

8. Kajal Savaliya. A critical analysis of micro insurance journal of research in commerce and management 2010;2(5):41-48. 